\title{
EFFECTIVENESS OF FICUS ELASTICA ROXB. EX HORNEM LEAF EXTRACT IN REDUCING TOTAL CHOLESTEROL LEVEL IN HIGH FAT INDUCED DIET WISTAR MALE RATS
}

\author{
Muhamad Seto Sudirman
}

\author{
School of Health Polytechnic, Pangkalpinang
}

\begin{abstract}
Background: Kebo rubber leaves (ficus elastica roxb) contain flavonoids, polyphenols, and tannins. Flavonoids in the leaves of ficus elastica roxb such as catechins, isoflavones are polyphenolic antioxidants from plant metabolites. The leaves of ficus elastica roxb are trusted and proven empirically in the community to reduce cholesterol levels in the blood. Mice choose animals because they are considered to have physiological similarities with humans. This study aimed to determine the effect of ethanol extract of ficus elastica roxb leaves on reducing total cholesterol level in male Swiss Webster mice.

Subjects and Method: This was a quasi-experimental study conducted at Biology Laboratory of the Faculty of Agriculture, Fisheries and Biology, University of Bangka Belitung from April to June, 2017. A sample of 25 male Swiss Webster mice was selected at random and allocated into groups. The dependent variable was total cholesterol. The independent variable was the extract of ficus elastica rox. The data were tested by One-Way ANOVA.

Result: There were statistically significant mean differences among the study groups $(p=0.002)$, indicating the effect of ethanol extract of Ficus Elastica Roxb leaves on reducing total cholesterol level in male Swiss Webster mice at various doses.

Conclusion: There are statistically significant mean differences among the study groups, indicating the effect of ethanol extract of Ficus Elastica Roxb leaves on reducing total cholesterol level in male Swiss Webster mice at various doses.
\end{abstract}

Keyword: Ethanol extract of Ficus Elastica Roxb leaves, total cholesterol, mice

Correspondence:

Muhamad Seto Sudirman. School of Health Polytechnic, Pangkalpinang. Email: MuhamadSeto@gmail.com

The $7^{\text {th }}$ International Conference on Public Health

Solo, Indonesia, November 18-19, 2020 378 https://doi.org/10.26911/the7thicph.05.10 